\section{Effect of Brassica Cover Crops and Hazelnut Husk Mulch on Weed Control in Hazelnut Orchards}

\author{
Husrev Mennan ${ }^{1}$ and Mathieu Ngouajio ${ }^{2,3}$
}

ADDITIONAL INDEX WORDs. Brassica juncea, Brassica napus, Brassica rapa, Corylus avellana, mustard, rape, weed management

SuMMARY. Weed management is critical in hazelnut (Corylus avellana) production. Weeds reduce nutrient availability, interfere with tree growth, and reduce handharvesting efficiency. Field experiments were conducted from Fall 2006 to 2010 to test effects of brassica (Brassica sp.) cover crops and hazelnut husk mulch as alternative weed management strategies in hazelnut. The cover crop treatments consisted of rape (Brassica napus), field mustard (Brassica rapa), oriental mustard (Brassica juncea), and fallow with no cover crop. Hazelnut husk was surface-applied at two thicknesses, 5- and 10-cm-thick layer. Dry biomass production by the cover crops was relatively consistent among years with oriental mustard producing the most biomass. Throughout the growing seasons, the cover crops reduced weed density, weed dry weight, and the number of weed species when compared with the fallow treatment. The most effective cover crop at suppressing weeds was oriental mustard. Hazelnut husk applied as a $10-\mathrm{cm}$-thick layer on the ground was highly effective at controlling weeds up to 180 days after application and reduced total weed dry weight by $83 \%$ at the end of the season. Our findings indicate that brassica cover crops or hazelnut husk may help control annual weed species in hazelnut orchards during early summer. However, these strategies should be combined with other methods like chemicals or cultivation for adequate weed management.

$\longrightarrow$ ultivated hazelnut is native to the Black Sea coast of northern Europe, and Turkey is one of the few countries in the world with a suitable climate for its production. Hazelnut is grown in both the eastern and western regions of Turkey along the Black Sea, on sharp slopes and in areas where the soil is unsuitable for other crops. The production areas extend up to $30-\mathrm{km}$ inland. Turkey produces over $70 \%$ of the world's hazelnut, followed by Italy, Spain, and the United States (Bozoğlu, 2002a), and hazelnut production has shown a general upward trend over the past decade (Bozoğlu, 2002b). The natural form of hazelnut is a multistemmed bush (called an ocak) grown in commercial orchards. In Turkey, hazelnut usually ripens from early to late August depending on the altitude and is harvested mainly by hand. The

Financial support for this work was provided in part by Agro Altin Company, Samsun, Turkey.

The authors would like to thank Volkan Ozturk and Tayfun Okan for their assistance in data collection.

${ }^{1}$ Department of Plant Protection, Agriculture Faculty, Ondokuz Mayıs University, 55139 Samsun, Turkey

${ }^{2}$ Department of Horticulture, Michigan State University, Plant and Soil Science Building, East Lansing, MI 48824

${ }^{3}$ Corresponding author. E-mail: ngouajio@msu.edu. relatively high rainfall and fertile soils of hazelnut orchards in the Black Sea region also favor establishment of a wide range of annual and perennial weed species.

Weed management is critical in hazelnut production to limit competition, conserve nutrients for the trees, and improve hand-harvesting efficiency. Ocak growing systems allow enough light penetration to the base of rows for extensive weed emergence and growth. Adequate weed control in hazelnut is normally achieved with two glyphosate applications, one in early spring and the other before harvest to facilitate the collection of nuts from the ground. However, alternative weed control strategies are needed for integrated weed management programs, particularly to prevent the development of herbicide resistance among weed populations (Holt et al., 1993).

Cover cropping could be an effective component of integrated weed management in hazelnut. Winter and cool season cover crops are grown for various reasons, including prevention of nitrogen leaching, water runoff, and soil erosion; improvement of soil structure; soil enrichment by nitrogen fixation (for legume species); habitat provision for beneficial insects; microclimate modification; and weed control (Haramoto and Gallandt, 2004; Mennan et al., 2006; Ngouajio and Mennan, 2005; Teasdale, 1996; Yenish et al., 1996).

Many studies have reported positive effects of living cover crops on early season weed suppression and growth either through direct competition (Ngouajio and Mennan, 2005; Yenish et al., 1996) or through allelopathic interactions (Barnes and Putnam, 1986). Furthermore, cover crop residues, whether incorporated or left on the soil surface, can affect weed dynamics by reducing or delaying seed germination, reducing establishment, and suppressing individual plant growth. Hence, cover cropping is recognized as an important tool for weed management. Rye (Secale cereale), ryegrass (Lolium multiflorum), hairy vetch (Vicia villosa), red clover (Trifolium pratense), and annual medics (Medicago sp.) have been used widely as winter cover crops to suppress broadleaf and grass weeds in diverse cropping systems. Recently, brassica cover crops have generated considerable interest because of their potential to inhibit seed germination and seedling growth (Ackroyd and Ngouajio, 2011; Brennan and Smith, 2005; Norsworthy et al.,

\begin{tabular}{llll}
\hline $\begin{array}{l}\text { Units } \\
\begin{array}{l}\text { To convert U.S. to SI, } \\
\text { multiply by }\end{array}\end{array}$ & U.S. unit & SI unit & $\begin{array}{l}\text { To convert SI to U.S., } \\
\text { multiply by }\end{array}$ \\
\hline 0.3048 & $\mathrm{ft}$ & $\mathrm{m}$ & 3.2808 \\
0.0929 & $\mathrm{ft}^{2}$ & $\mathrm{~m}^{2}$ & 10.7639 \\
2.54 & inch $(\mathrm{es})$ & $\mathrm{cm}$ & 0.3937 \\
25.4 & inch $(\mathrm{es})$ & $\mathrm{mm}$ & 0.0394 \\
0.4536 & $\mathrm{lb}$ & $\mathrm{kg}$ & 2.2046 \\
1.1209 & $\mathrm{lb} / \mathrm{acre}$ & $\mathrm{kg} \cdot \mathrm{ha}^{-1}$ & 0.8922 \\
28.3495 & $\mathrm{Oz}$ & $\mathrm{g}$ & 0.0353 \\
305.1517 & $\mathrm{Oz} / \mathrm{ft}^{2}$ & $\mathrm{~g} \cdot \mathrm{m}^{-2}$ & 0.0033 \\
0.9072 & $\mathrm{ton}(\mathrm{s})$ & $\mathrm{Mg}$ & 1.1023 \\
$\left({ }^{\circ} \mathrm{F}-32\right) \div 1.8$ & ${ }^{\circ} \mathrm{F}$ & ${ }^{\circ} \mathrm{C}$ & $\left(1.8 \times{ }^{\circ} \mathrm{C}\right)+32$ \\
& & &
\end{tabular}


2011 ; Petersen et al., 2001). Brassicaceae species contain glucosinolates, which after enzymatic hydrolysis release isothiocyanates-well known allelopathic substances that may suppress weeds.

Weed control without the use of herbicides could be ineffective, expensive, and time-consuming in orchard management and therefore should be investigated before making recommendations to growers. Mulches used to control weeds have been reported to be beneficial for tree growth and yield (Belding et al., 2004; Childers et al., 1995; Stafne et al., 2009). Among these materials, cereal straw is one of the most commonly used products in vegetable production or orchard management. Unfortunately, little is known about hazelnut husk residues used as mulch and their allelopathic properties, which could contribute to weed suppression. Each year, $\approx 400,000-500,000 \mathrm{Mg}$ of hazelnut husk residue is burned or left in the field after harvest (Çöpür et al., 2007). This important organic waste could be incorporated into weed management programs in hazelnut orchards if proven effective.

Hazelnut growers need alternative or supplemental weed management strategies that can provide adequate weed control while maintaining optimum yield. Therefore, the goal of this study was to improve weed management programs in hazelnut production. Specific objectives were to determine the impact of brassica cover crops on weed control and to assess possible contributions of hazelnut husk as organic mulch for weed control.

\section{Materials and methods}

Experimental AREA. Field experiments were initiated in Fall 2006 and conducted until 2010 in Samsun, Turkey, on a sandy clay soil $(44 \%$ sand, $16 \%$ silt, $38 \%$ clay, $2.1 \%$ organic matter, and $\mathrm{pH} 6.3$ ). The hazelnut orchard with multistemmed bush trees (ocak) used was 4 years old at the beginning of the experiments. Each ocak had six to eight stems. Plant spacing was $2.5 \mathrm{~m}$ in the row and $4.5 \mathrm{~m}$ between rows. Individual plots had two rows and a total of four ocaks. At the beginning of experiment in the fall, the site was fertilized once with $42 \%$ triple super phosphate $\left[\mathrm{P}_{2} \mathrm{O}_{5}\right.$ (Toros Gubre; Istanbul, Turkey)] at $200 \mathrm{~g}$ (87.4 g phosphorus) per ocak. In each year, nitrogen in the form of ammonium sulfate [21\% nitrogen (Toros Gubre)] was applied at $200 \mathrm{~g}$ (42.0 g nitrogen and $48.0 \mathrm{~g}$ sulfur) per ocak with two equal split applications in early March and in mid-June. Average temperatures and precipitation at the experimental site are presented in Fig. 1.

COVER CROP EXPERIMENT. The cover crop treatments consisted of rape, field mustard, oriental mustard, and bare ground with no cover crop. The brassica cover crops were seeded by hand on 4 Nov. 2006, 3 Nov. 2007, 8 Nov. 2008, and 14 Nov. 2009 , respectively. The seed was broadcast at $12 \mathrm{~kg} \cdot \mathrm{ha}^{-1}$ for each species and incorporated into the soil to a depth of $\approx 1$ to $2 \mathrm{~cm}$. Treatments were arranged in a randomized complete block design with four replications. Each plot was $20 \mathrm{~m}^{2}(4 \times 5 \mathrm{~m})$. Consecutive plots were separated by a buffer zone with no cover crop. The treatments were maintained exactly on the same plots all 4 years to capture cumulative effects of the cover crops. At the flowering stage of the cover crops, all plants (including weeds in the control plots) were incorporated into the soil by rotary hoeing. This corresponded to 12 May 2007, 14 May 2008, 9 May 2009, and 16 May 2010 , respectively.

Before incorporation, the cover crops were sampled to estimate aboveground biomass and assess weed populations. Four $0.250-\mathrm{m}^{2}$ quadrants were sampled per plot. To determine the weed suppressive effects of the cover crops, weed density and total weed dry biomass were assessed before and at 14, 28, and $56 \mathrm{~d}$ after incorporation (DAI) from all plots using a $0.250-\mathrm{m}^{2}$ quadrant placed randomly on the plots. Weeds and cover crops were dried at $65^{\circ} \mathrm{C}$ for $96 \mathrm{~h}$ and weighed.

HAzelnut HUSK EXPERIMENT. Hazelnut husk was obtained from a local producer each year after threshing and stored at $-5^{\circ} \mathrm{C}$ until needed. Treatments consisted of hazelnut husk that was surface applied at either 5- or $10-\mathrm{cm}$ deep in the entire row and bare ground with no mulch. The experiment was arranged in a randomized complete block design with four replications. Each plot was $15 \mathrm{~m}^{2}(1.5 \times$ $10 \mathrm{~m}$ ) with four ocaks. Consecutive plots were separated with a buffer zone and treatments were maintained exactly on the same plots for all 4 years to capture cumulative effects. Hazelnut husk mulch was applied on the soil surface at a rate of $200 \mathrm{~kg}$ per plot for $10-\mathrm{cm}$-thick (hereafter called

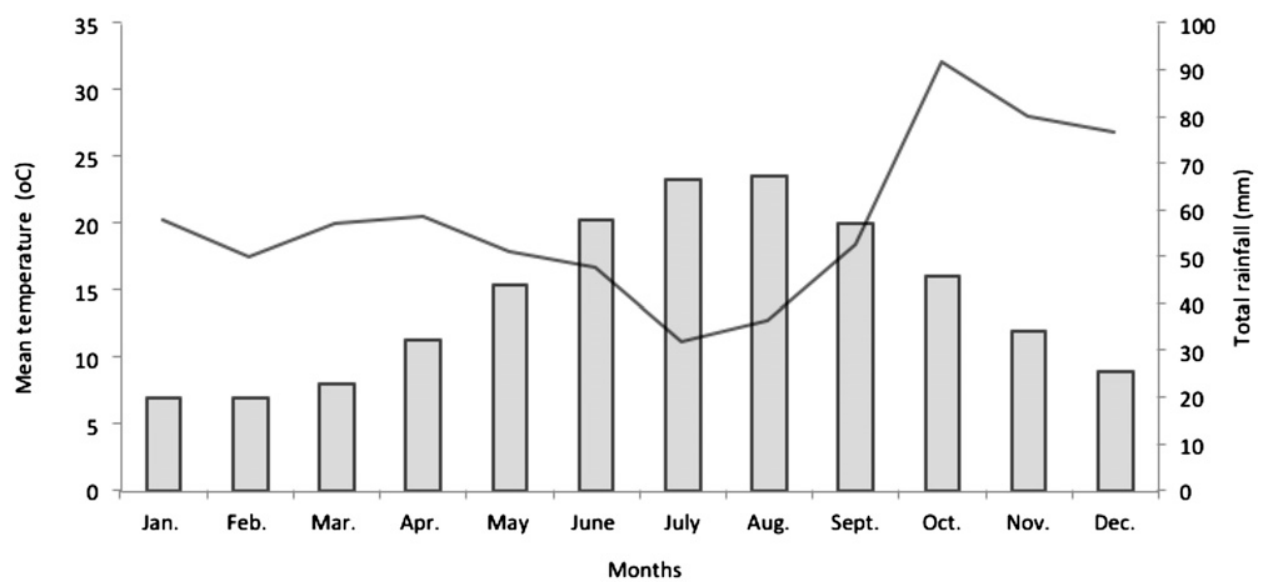

Fig. 1. Average temperatures and precipitation at the experimental site in Samsun, Turkey (mean of 2006-10). The line represents rainfall and the bars represent temperature; $\left(1.8 \times{ }^{\circ} \mathrm{C}\right)+32={ }^{\circ} \mathrm{F}, 1 \mathrm{~mm}=0.0394 \mathrm{inch}$. 
high rate) and $100 \mathrm{~kg}$ per plot for 5 $\mathrm{cm}$-thick (hereafter called low rate) treatments on the same day when the cover crops were seeded. Additional hazelnut husk was added in March of each year $(\approx 50 \%$ of the initial amount) to maintain the appropriate mulch thickness.

Weed density and total weed dry biomass were assessed at 30, 60, 90, 120,150 , and $180 \mathrm{~d}$ after application (DAA) of the mulch for all plots using a $0.250-\mathrm{m}^{2}$ quadrant placed randomly on the plots. Weed dry weight was measured as indicated above.

Statistical analyses. Data across all years were subjected to analysis of variance. When year-by-treatment interaction effects were significant, data were presented for each year separately. To satisfy assumptions of equal variance, natural $\log$ transformations were applied to cover crop biomass, weed density, and weed dry weight. However, nontransformed means are presented in the text for clarity of

Table 1. Main broadleaf and grass weed species present at the experimental site in Samsun, Turkey, and their relative proportion (means of 2006-10 combined).

\begin{tabular}{lllc}
\hline Group & \multicolumn{1}{c}{ Common name } & Bayer code & $\begin{array}{c}\text { Relative } \\
\text { proportion (\%) }\end{array}$ \\
\hline Broadleaved & English daisy & BELPE & 10 \\
& Shepherd's purse & CAPBP & 8 \\
& Fugwort & ARTVU & 6 \\
& Field bindweed & CONAR & 6 \\
& Burning nettle & GALAP & 5 \\
& Fumitory & URTUR & 5 \\
Wild mustard & FUMOF & 4 \\
& Wild chamomile & SINAR & 4 \\
& Brackenfern & MATCH & 3 \\
& PTEAQ & 3 \\
Grasses & & 9 \\
& Blackgrass & ALOMY & 7 \\
& Perennial ryegrass & LOLPE & 6 \\
& Poverty brome & BROST & 4 \\
& Bermudagrass & CYNDA & 4 \\
Annual bluegrass & POAAN & 3 \\
Green foxtail & SETVI & 3
\end{tabular}

Others ${ }^{\mathrm{y}}$

${ }^{2}$ Names of weeds are described by five-letter Bayer code (Weed Science Society of America, 2010).

'This includes all weed species that were present at less than $2 \%$. presentation. Means were separated using Fisher's protected least significant difference procedure.

\section{Results and discussion}

BASELINE WEED POPULATIONS. In general, the most frequent species were the same in all treatments, and their relative proportion at the beginning of the experiment was relatively uniform. In each year, $\approx 20$ species belonging to 10 families were recorded across all experiments and treatments. The composition of the weed flora in the experimental area and the proportion of broadleaf and grass species are shown in Table 1. The most prominent weeds were english daisy (Bellis perennis), shepherd's purse (Capsella bursa-pastoris), mugwort (Artemisia vulgaris), field bindweed (Convolvulus arvensis), catchweed bedstraw (Galium aparine), burning nettle (Urtica urens), fumitory (Fumaria officinalis), wild mustard (Sinapis arvensis), wild chamomile (Matricaria chamomilla), brackenfern (Pteridium aquilinum), blackgrass (Alopecurus myosuroides), perennial ryegrass (Lolium perenne), poverty brome (Bromussterilis), bermudagrass (Cynodon dactylon), annual bluegrass (Poa annua), green foxtail (Setaria viridis), and large crabgrass (Digitaria sanguinalis). Weed counts and weed dry weights taken in all years showed that english daisy (10\%), blackgrass $(9 \%)$, shepherd's purse $(8 \%)$, perennial ryegrass $(7 \%)$, mugwort $(6 \%)$, field bindweed $(6 \%)$, and poverty brome $(6 \%)$ accounted for over $50 \%$ of the total weed populations.

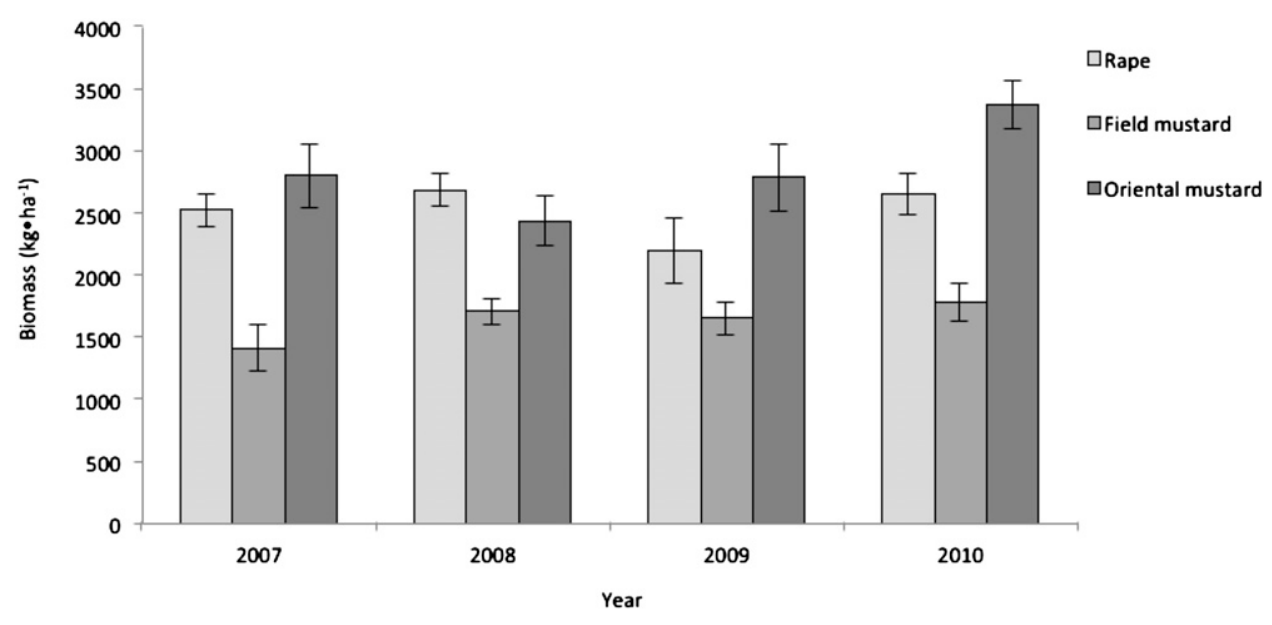

Fig. 2. Dry biomass production of the cover crops before incorporation in Samsun, Turkey. Four $0.250-\mathrm{m}^{2}\left(2.6910 \mathrm{ft}^{2}\right)$ quadrants were sampled per plot. Samples were dried at $65^{\circ} \mathrm{C}\left(149.0^{\circ} \mathrm{F}\right)$ for $96 \mathrm{~h}$ and weighed. Vertical lines represent sE; $1 \mathrm{~kg} \cdot \mathrm{ha}^{-1}=0.8922 \mathrm{lb} /$ acre. 
EFFECTS OF COVER CROP ON WEED populations. Cover crop establishment varied among years with the best stand observed in 2010 (data not shown). The high cover crop stand in 2010 was probably due to more optimal seed placement and uniform rainfall pattern in the fall. At the time of cover crop termination in all years, $\approx 70 \%$ of the plants were at flowering stage. The performance of the cover crops with respect to biomass production was relatively consistent across all years of the study, with oriental mustard producing more biomass than the other species except in 2008 (Fig. 2). Oriental mustard produced $3367 \mathrm{~kg} \cdot \mathrm{ha}^{-1}$ biomass in 2010 , followed by rape and field mustard with 2656 and $1782 \mathrm{~kg} \cdot \mathrm{ha}^{-1}$, respectively. Cover crop biomass production in 2008 was low in oriental mustard, likely as a result of unusually cool weather following planting.

The year-by-treatment interaction was significant for weed density at $0,14,28$, and 56 DAI. Therefore, data were analyzed by year and by evaluation date. In 2007, there were significant differences in weed densities following incorporation of the cover crops (Table 2). All cover crops reduced total weed density compared with the fallow system, but differences among cover crops were not significant before cover crop incorporation. Oriental mustard was the most promising cover crop and reduced weed density by over $84 \%, 85 \%$, and $78 \%$ at 14,28 , and 56 DAI, respectively. Similar results were obtained with rape and field mustard treatments at all evaluation dates (Table $2)$. There was lower cover crop biomass in 2008 than in other years, but the relative effects of the cover crops on weed density remained consistent (Table 2). Weed density was highest in the no cover crop treatment followed by rape, field mustard, and oriental mustard in 2008 before incorporation of cover crops. In subsequent years, there were few weeds in cover crop treatments before cover crop incorporation, probably because of high amounts of biomass produced by the cover crops. Assessments before cover crop incorporation in 2009 and 2010 showed $\approx 70 \%$ reduction in weed density compared with the no cover crop treatment. Reductions in total weed density were also observed in both years at 14 DAI (Table 2).
This reduction was more marked at 28 and 56 DAI. Overall, oriental mustard provided the greatest weed suppression over the 4 years.

Cover crops and cover crop residues often are reported to reduce early season weed density and weed seedling emergence, particularly for summer annual weeds that are responsive to temperature and light, by direct competition from cover crop biomass (Mennan et al., 2009; Teasdale, 1996) or by allelopathy (Barnes and Putnam, 1986). Boydston and Hang (1995) indicated that 410 to $580 \mathrm{~g} \cdot \mathrm{m}^{-2}$ of dry overwintered rapeseed incorporated before planting potato reduced midseason weed density by $73 \%$ to $85 \%$ compared with fallow.

The relative effects of the cover crops on weed dry biomass production just before incorporation varied with year (Table 3 ). Data were analyzed by year and by evaluation date because the interaction of year by treatment was significant. At the time of cover crop incorporation in 2007, weed dry biomass was highest in the fallow treatment $\left(852 \mathrm{~g} \cdot \mathrm{m}^{-2}\right)$ followed by field mustard $\left(250 \mathrm{~g} \cdot \mathrm{m}^{-2}\right)$, rape $\left(201 \mathrm{~g} \cdot \mathrm{m}^{-2}\right)$, and oriental mustard $\left(178 \mathrm{~g} \cdot \mathrm{m}^{-2}\right)$. Similar trends were observed in subsequent years. After incorporation of the cover crops, field mustard, rape, and oriental mustard residues significantly reduced total weed dry biomass in all years at 14 DAI, but differences among cover crops were not significant (Table 3 ). With assessments at 28 or 56 DAI, weed biomass reduction by the cover crops followed trends observed at the time of cover crop incorporation. The most effective cover crop in all years was oriental mustard and reduced total weed dry biomass at 28 DAI by $87.4 \%, 80.9 \%, 76.7 \%$, and $83.9 \%$ in 2007, 2008, 2009, and 2010, respectively.

Previous studies have indicated that many cover crops including brassicas, cereals (Poaceae), legumes (Leguminosae), and sorghum (Sorghum sp.) have the ability to reduce weed dry weight and weed density in various crops (Al-Khatib et al., 1997; Fisk et al., 2001; Mennan et al., 2006; Norsworthy et al., 2011). Biomass production is a strong determinant of the degree of early season weed suppression in many crops. However, the length of weed suppression by residues will depend on biomass

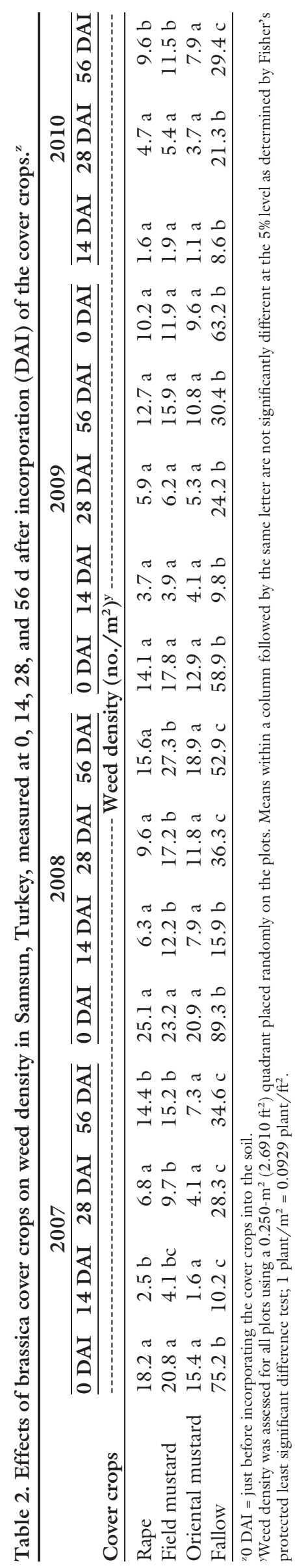

Hortlechnology · February 2012 22(1) 


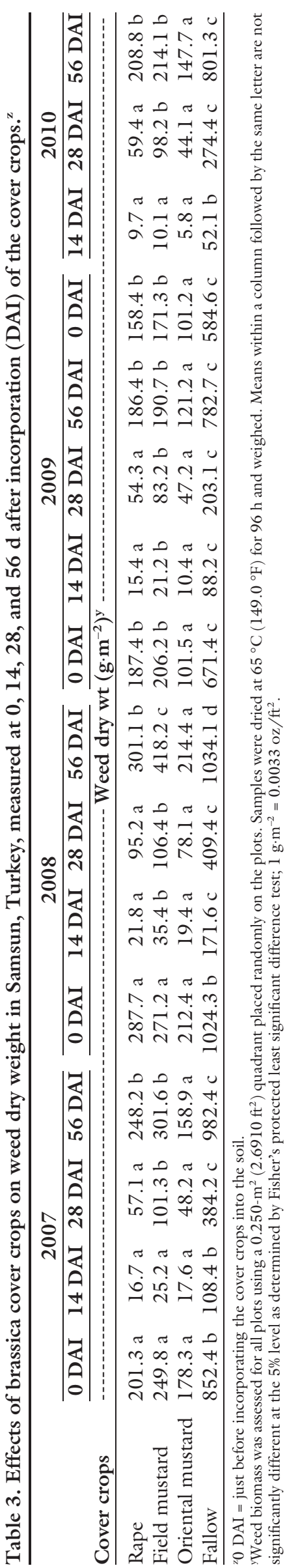

persistence, which will determine the extent and length of microenvironment modification. Decomposing cover crop residue provides physical and allelopathic effects that can reduce both weed germination and growth. Cover crop residue suppresses weeds by modifying the light, temperature, moisture, and chemical environment of germinating seeds (Teasdale et al., 1991). In addition, brassica cover crops have the ability to produce glucosinolates, which form isothiocyanates upon tissue degradation. These substances have allelopathic potential and are known to suppress weeds in several crops (Haramoto and Gallandt, 2004; Malik et al., 2008; Norsworthy et al., 2005).

When cover crop treatments were evaluated for weed suppression on the basis of weed species, it was clear that all cover crop residues inhibited germination and growth of annual weeds including english daisy, shepherd's purse, catchweed bedstraw, fumitory, mustard, wild chamomile, and annual bluegrass compared with the system with no cover crop (data not shown). However, cover crop residues failed to suppress burning nettle, mugwort, field bindweed, brackenfern, perennial ryegrass, and bermudagrass. Failure of the cover crop residues to affect these weeds was expected because these weeds are perennial and difficult to control even with herbicides. Our findings indicated that cover crops suppressed many weed species in hazelnut orchards during early summer, but the level of weed control did not match what is generally achieved with herbicides. Therefore, the cover crops should not be used as the only weed control method.

EFFeCt OF HAZELNUT HUSK MULCH ON WEED POPULATIONS. Data were combined for all years because the interaction of year by treatment was not significant. As expected, the fallow treatment without mulch had a higher total weed density and weed dry weight than both treatments with hazelnut husk residues (Figs. 3 and 4). The low husk residue treatment reduced emergence of various weed species by $58 \%$ to $87 \%$ compared with fallow at 30 DAA (Fig. 3). Similar trends were observed until the last evaluation date at $180 \mathrm{DAA}$. With the high hazelnut husk residue, no weeds were recorded in the plot until 90 DAA. Thereafter, weed density was extremely low, with a reduction of over $95 \%$. Applying hazelnut husk at either low or high residue levels led to a significant decrease in the weed density when compared with the control. Total weed density in low and high residue plots were only 14.6 and 7.2 plants $/ \mathrm{m}^{2}$ at $180 \mathrm{DAA}$, respectively, corresponding to a $52.2 \%$ and $76.2 \%$ weed density reduction compared with the control. Most of the weed species in low and high residue plots were perennial thick-stemmed weeds like burning nettle and mugwort that penetrated the residue after application. There were also some annuals and perennials such as blackgrass and bermudagrass that emerged directly on top of the residue. Hazelnut husk treatments (either low or high residue) reduced emergence of all other weed species present in the experimental area compared with the control.

The relative effects of residue on weed dry biomass production after application were consistent each year and mimicked results observed with weed density (Fig. 4). Low and high residue treatments reduced total weed dry biomass measured on the last assessment day by $60 \%$ and $83 \%$, respectively.

Improvements in weed control as a result of mulching have been reported previously for orchard systems, even resulting in benefits for tree growth and yield (Belding et al., 2004; Childers et al., 1995). Applying mulch directly on top of mature weeds or germinating seeds may damage them by preventing light penetration, interfering with stem elongation, encouraging fungal growth through increased moisture, and by acting as a physical barrier to growth. The overall results of this experiment show that a hazelnut husk mulch can control weeds in hazelnut orchards when maintained at a depth of at least $5 \mathrm{~cm}$ through multiple applications, but to obtain a higher level of weed control to ensure suitable yield production, this method should be combined with other weed management techniques like chemicals or cultivation. In addition to weed control, this organic mulch also has the advantage of biodegradability, and during degradation, the mulch could release nutrients and improve soil organic matter content. It can be purchased from local producers at low cost in Turkey and it may be 


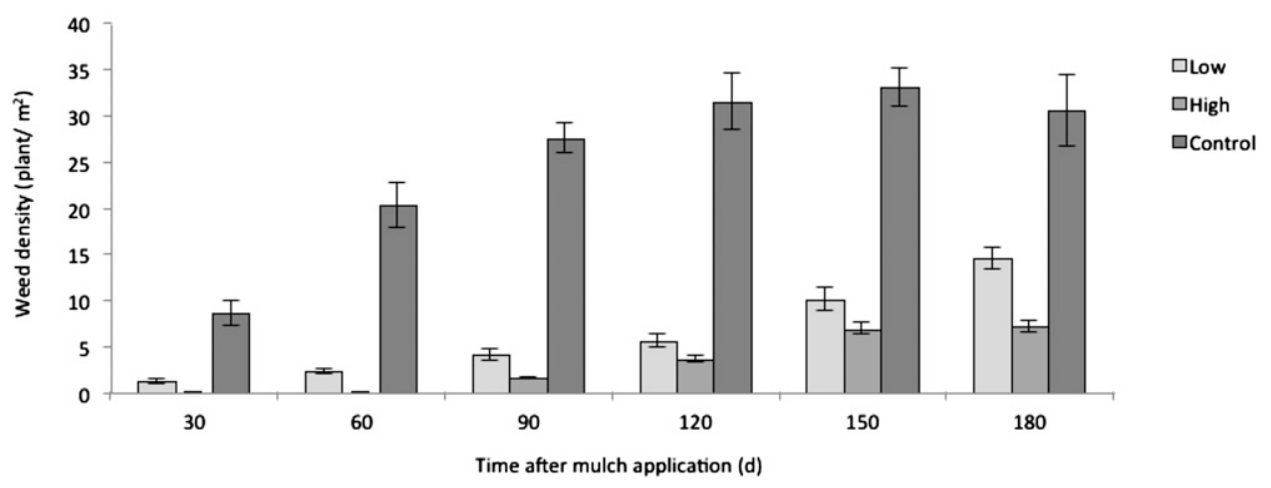

Fig. 3. Effect of hazelnut husk mulch applied at different thicknesses on weed density in Samsun, Turkey. Vertical lines represent SE of the means. DAA is days after mulch application. Low and High represent 5 - and 10 -cm-thick (2.0 and 3.9 inches) hazelnut mulch treatments, respectively. Weed density was assessed at 30,60, 90, 120, 150, and $180 \mathrm{~d}$ after application (DAA) of the mulch for all plots using a $0.250-\mathrm{m}^{2}\left(2.6910 \mathrm{ft}^{2}\right)$ quadrant placed randomly on the plots; $1 \mathrm{plant} / \mathrm{m}^{2}=0.0929 \mathrm{plant} / \mathrm{ft}^{2}$.

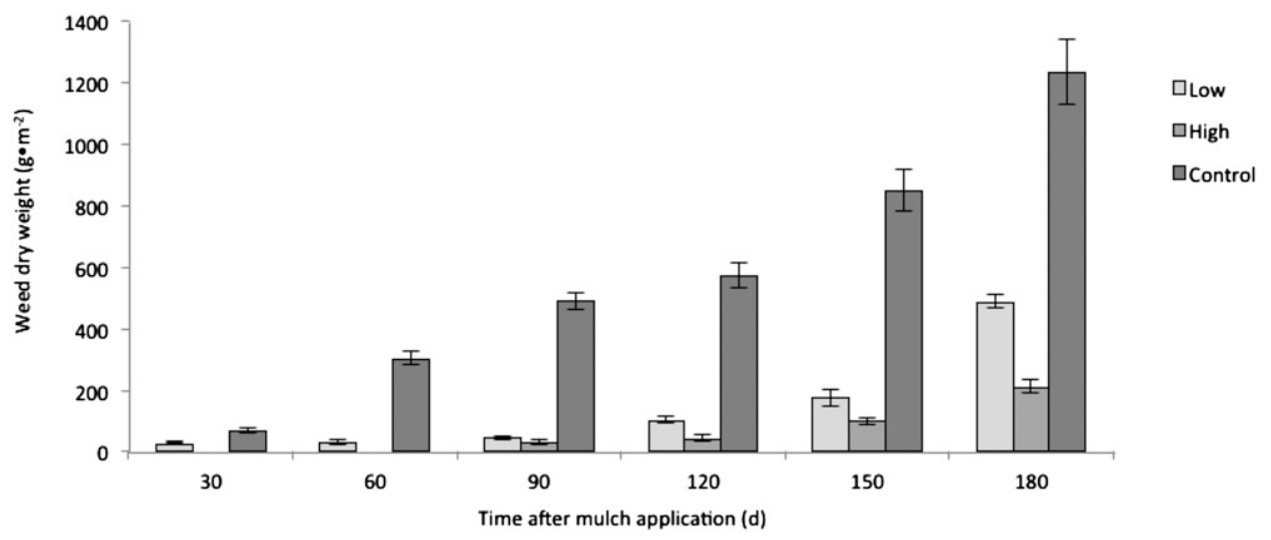

Fig. 4. Effect of hazelnut husk applied at different thicknesses on weed dry weight in Samsun, Turkey. Vertical lines represent sE of the means. AA is days after mulch application. Low and High represent 5- and 10-cm-thick (2.0 and 3.9 inches) hazelnut mulch treatments, respectively. Weed dry biomass were assessed at 30,60, 90, 120, 150, and $180 \mathrm{~d}$ after application (DAA) of the mulch for all plots using a $0.250-\mathrm{m}^{2}\left(2.6910 \mathrm{ft}^{2}\right)$ quadrant placed randomly on the plots. Samples were dried at $65{ }^{\circ} \mathrm{C}$ $\left(149.0{ }^{\circ} \mathrm{F}\right.$ ) for $96 \mathrm{~h}$ and weighed; $1 \mathrm{~g} \cdot \mathrm{m}^{-2}=0.0033 \mathrm{oz} / \mathrm{ft}^{2}$.

spread before postemergence herbicide applications. However, if every hazelnut grower were to apply hazelnut husk as a mulch, the demand would far exceed supply.

Successful weed management programs in orchards require a comprehensive approach that uses a combination of weed control practices and alternates them over several years. The use of cover crops and hazelnut husks as a mulch could help reduce initial weed populations and improve weed control. Brassica cover crops have a number of beneficial attributes, including rapid fall growth and high biomass production, contributing to good competitiveness with other plants. However, early season weed suppression by cover crops and mulch must be combined with herbicides or cultivation to avoid crop yield losses from weed competition later in the season. Also, combining cover crops and mulching with other control strategies would help prevent weed population shifts in favor of perennial species. Therefore, an effective weed management system in hazelnut could include brassica cover crops or hazelnut husk followed by herbicide applications for postemergence control of weeds. This weed management program could improve weed control while reducing overall reliance on herbicides for sustainable hazelnut production.

\section{Literature cited}

Ackroyd, J.V. and M. Ngouajio. 2011. Brassicaceae cover crops affect seed germination and seedling establishment in cucurbit crops. HortTechnology 21:525-532.

Al-Khatib, K., C. Libbey, and R. Boydston. 1997. Weed suppression with Brassica green manure crops in green pea. Weed Sci. 45:439-445.

Barnes, J.P. and A.R. Putnam. 1986. Evidence for allelopathy by residues and aqueous extracts of rye (Secale cereale). Weed Sci. 34:384-390.

Belding, R.D., B.A. Majek, G.R.W. Lokaj, J. Hammerstedt, and A.O. Ayeni. 2004. Orchard floor management influence on summer annual weeds and young peach tree performance. Weed Technol. 18:215-222.

Boydston, R. and A. Hang. 1995. Rapeseed (Brassica napus) green manure crop suppresses weeds in potato (Solanum tuberosum). Weed Technol. 9:669-675.

Bozoğlu, M. 2002a. Turkiye'nin fndik politikası ve refrom arayıslar1. Turkiye'de uygulanan findık politikaları ve findigın gelecegi konferans paneli. Ondokuz Mayıs Universitesi Ziraat Fakultesi 2:9-24. 
Bozoğlu, M. 2002b. The situation of the hazelnut sector in Turkey. Acta Hort. 686:641-648.

Brennan, E.B. and R.F. Smith. 2005. Winter cover crop growth and weed suppression on the central coast of California. Weed Technol. 19:1017-1024.

Childers, N.F., J.R. Morris, and G.S. Sibbett. 1995. Modern fruit science. Horticultural Publications, Gainesville, FL.

Çöpür, Y., C. Güler, M. Akgül, and C. Taşçığlu. 2007. Some chemical properties of hazelnut husk and its suitability for particleboard production. Build. Environ. 42:2568-2572.

Fisk, J.W., O.B. Hesterman, A. Shrestha, J.J. Kells, R.R. Harwood, J.M. Squire, and C.C. Sheaffer. 2001. Weed suppression by annual legume cover crops in notillage corn. Agron. J. 93:319-325.

Haramoto, E.R. and E.R. Gallandt. 2004. Brassica cover cropping for weed management: A review. Renewable Agr. Food System 19:187-198.

Holt, J.S., S.B. Powles, and J.A.M. Holtum. 1993. Mechanisms and agronomic aspect of herbicides resistance. Annu. Rev. Plant Physiol. Plant Mol. Biol. 44:203-229.
Malik, M.S., J.K. Norsworthy, A.S. Culpepper, M.B. Riley, and W. Bridges. 2008. Use of wild radish (Raphanus raphanistrum) and rye cover crops for weed suppression in sweet corn. Weed Sci. 56:588-595.

Mennan, H., M. Ngouajio, D. Isik, and E. Kaya. 2006. Effect of alternative management systems on weed populations in hazelnut (Corylus avellana L.). Crop Protection 25:835-841.

Mennan, H., M. Ngouajio, D. Isik, and E. Kaya. 2009. Effects of alternative winter cover cropping systems on weed suppression in organically grown tomato (Solanum lycopersicum). Phytoparasitica 37:385-396.

Ngouajio, M. and H. Mennan. 2005. Weed populations and pickling cucumber (Cucumis sativus) yield under summer and winter cover crop systems. Crop Protection 6:521-526.

Norsworthy, J.K., L. Brandenberger, N.R. Burgos, and M. Riley. 2005. Weed suppression in Vigna unguiculata with a spring-seeded Brassicaceae green manure. Crop Protection 24:441-447.

Norsworthy, J.K., M. McClelland, G. Griffith, S.K. Bangarwa, and J. Still.
2011. Evaluation of cereal and Brassicaceae cover crops in conservation-tillage enhanced, glyphosate-resistant cotton. Weed Technol. 25:6-13.

Petersen, J., R. Belz, F. Walker, and K. Hurle. 2001. Weed suppression by release of isothicyanates from turnip-rape mulch. Agron. J. 93:37-43.

Stafne, E.T., C.T. Rohla, and B.L. Carroll. 2009. Pecan shell mulch impact on 'Loring' peach tree establishment and first harvest. HortTechnology 19:775-780.

Teasdale, J.R., C.E. Beste, and W.E. Potts. 1991. Response of weeds to tillage and cover crop residue. Weed Sci. 39: 195-199.

Teasdale, J.R. 1996. Contribution of cover crops to weed management in sustainable agricultural systems. J. Prod. Agr. 9:475-479.

Weed Science Society of America. 2010. Composite List of Weeds. 27 Dec. 2011. <http://wssa.net/Weeds/ID/ WeedNames/CompositeListOfWeeds_pdf. zip>.

Yenish, J.P., A.D. Worsham, and A.C. York. 1996. Cover crops for herbicide replacement in no-tillage corn (Zea mays). Weed Technol. 10:815-821. 